Canadian University Music Review

Canadian University Music Review

Revue de musique des universités canadiennes

\title{
Proserpina Rapita: an Unknown Opera Fragment
}

\section{Mary Térey-Smith}

Volume 10, numéro 1, 1990

URI : https://id.erudit.org/iderudit/1014894ar

DOI : https://doi.org/10.7202/1014894ar

Aller au sommaire du numéro

Éditeur(s)

Canadian University Music Society / Société de musique des universités

canadiennes

ISSN

0710-0353 (imprimé)

2291-2436 (numérique)

Découvrir la revue

Citer cet article

Térey-Smith, M. (1990). Proserpina Rapita: an Unknown Opera Fragment.

Canadian University Music Review / Revue de musique des universités

canadiennes, 10(1), 40-54. https://doi.org/10.7202/1014894ar

All Rights Reserved (C Canadian University Music Society / Société de musique des universités canadiennes, 1990
Ce document est protégé par la loi sur le droit d'auteur. L’utilisation des services d'Érudit (y compris la reproduction) est assujettie à sa politique d'utilisation que vous pouvez consulter en ligne.

https://apropos.erudit.org/fr/usagers/politique-dutilisation/ 


\title{
PROSERPINA RAPITA: AN UNKNOWN OPERA FRAGMENT*
}

\author{
Mary Térey-Smith
}

Sacrati, Francesco . . . Italian composer . . . was active in Venice as a composer of opera during the early 1640's . . . was highly esteemed by his contemporaries. Prince Matthias de Medici called him "one of the best composers around" . . None of his works is known to survive. ${ }^{1}$ [Walker 1980: 16/377]

The Bayerische Staatsbibliothek in Munich houses a large manuscript collection of Baroque opera excerpts from the bequest of Adolf Sandberger, catalogued as "Opernfragmente, Mus. Mss. 5734."2 Preserved in three separate portfolios, the fragments contain Italian, German, French and English selections spanning the seventeenth and the eighteenth centuries by a wide range of composers, from the famous to the barely known. There is a special Venetian folder in the second volume, entitled "Opernfragmente, Venetianische Schule,"

* I wish to express my thanks to Dr. Günter Brosche, director of the Musiksammlung, ÖNB, and to the staff for their assistance and for permission to use the material. A similar appreciation is due to the staff of the Bayerische Staatsbibliothek and to Director Dr. Robert Münster (Musiksammlung) for their help in locating the collection, for the microfilm and for the written authorization concerning the "Fragmente."

1 In a recent correspondence Professor Lorenzo Bianconi (University of Bologna) informed me that he is preparing an edition of Sacrati's extant music. Apparently, a few pieces of his output survived, mostly in private collections.

Adolf Sandberger (1864-1943), founder of the Musicological Seminar at the University of Munich, an early editor of Denkmäler der Tonkunst in Bayern and the Neues Beethoven-Jahrbuch, was an outstanding leader in the development of modern historical musicology in Germany and the teacher of many internationally known music historians, Alfred Einstein, Karl Fellerer, Arnold and Eugen Schmitz among them. Sandberger's interests ranged from Lassus to Peter Cornelius, and Baroque opera had a special fascination for him. As the "Fragmente" suggest, he might have been contemplating a major study in this field but - beyond a number of individual articles - never got around to complete the project. 
that contains the music of Boretti, Cavalli, Cesti, Ferrari, Freschi, Legrenzi, Pallavicino, Pollaroli, Sacrati, Sartorio, Varischino and Ziani. To find Sacrati's name among these composers is surprising since all references to him in music literature declare his works for the stage to be lost.

The title page, written on stave paper in Latin script, reads:

“Mus. Mss. 5734 /VI. 24”

"Copie aus der Hofbibliothek, Wien"3

\author{
PROSERPINA RAPITA \\ Drama per musica \\ Poesia di Giulio Strozzi \\ Musica di Francesco Sacrati
}

Covering ten pages, the music includes a Sonata (a 5), Proserpina's lament and the subsequent recitative (Scene 1, Act I), and a duet between Proserpina and Plutone (Scene 2).

A letter, addressed to Sandberger, is appended to the score:

K.u.K. Hof-Bibliothek

Wien, den 11. Oktober 1913.

I, Josefplatz Nr. 1.

Verehrtester Herr Professor!

An Stelle des Herrn Dr. Lach - der in Berlin war - habe ich beiliegende Kopie anfertigen lassen. An einer Stelle ist der Text unleserlich. Molitor hat in seiner Abschrift das Wort gleichfalls nur markiert. Den Noten beigebend ist ein kleiner Zettel, auf dem Molitor einen hinweis auf Winterfelds Gabrieli, III Teil, pag 65. gibt und die Verwendung der Blasinstrumente zum Gesang bespricht. Die Kosten für Kopie und Post $-4 \mathrm{~K}$. - bitte ich behufs Weiterleitung an meine Adresse senden zu wollen.

Mit Ausdrucke

$$
\begin{aligned}
& \text { meiner Verehrung } \\
& \text { Dr. Hans Johann } \\
& \text { Musikalien Sammlung. }
\end{aligned}
$$

("Vienna, October 11, 1913. Highly esteemed Professor [Sandberger]! In place of Dr. Lach, who was in Berlin, I have arranged the copying of the

3 Holdings of the former Hofbibliothek are today part of the Österreichische Nationalbibliothek in Vienna. 
11

K. K. HOF-BIBLIOTHEK.

1. Joselspiatz $\mathrm{Nr}$. 1

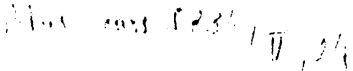

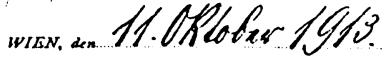

yourtested Hert Propessor!

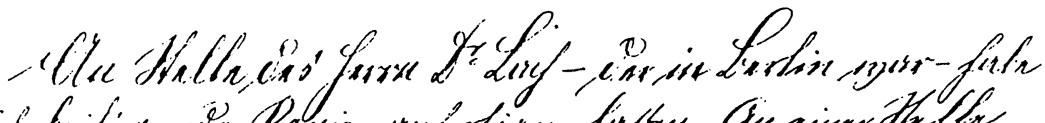

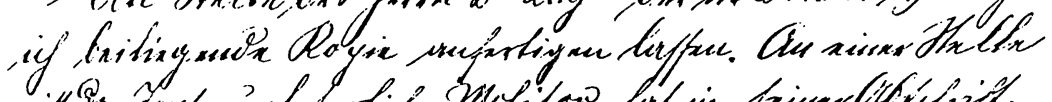

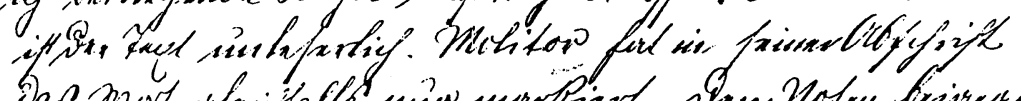

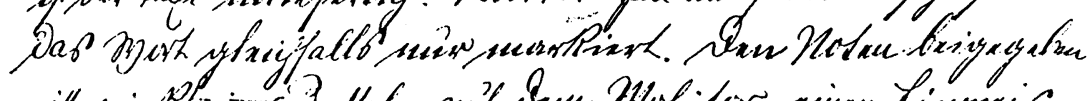

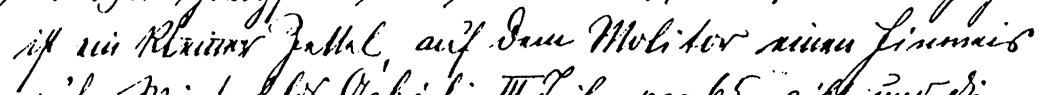

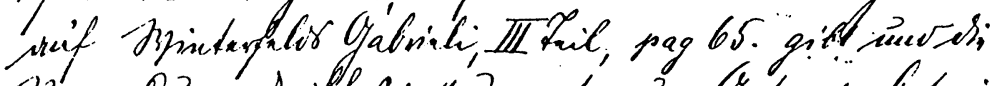

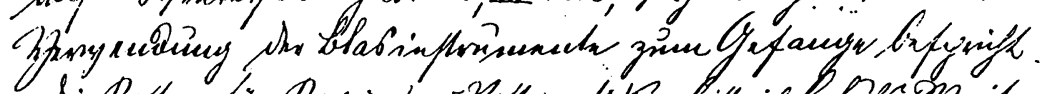

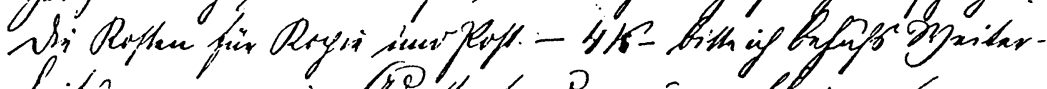

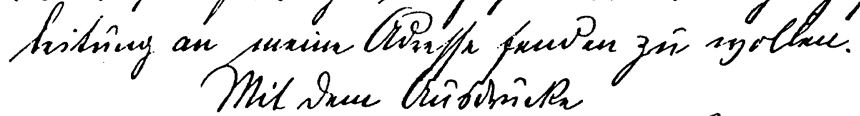

thry shomilualt

$$
13 . x^{2}, 13
$$

suxiuser Trunginicy

Sigans fofaue

Arsin, Loptsiblity s. Phipitration-Dawsulenung.

42 
enclosed material. At one point the text is illegible. Molitor ${ }^{4}$ in his copy just wrote down the word in a similar manner. Appended to the score is a little piece of paper on which Molitor refers to Winterfeld's Gabrieli, part III, page 65 , which concerns the use of wind instruments for vocal accompaniment. The costs relative to duplication and postage, 4 crowns, please mail to my address. With expressions of my admiration, Dr. Hans Johann, Vienna, Hofbibliothek, Music Division.")

In order to examine the source of the fragment, I requested a copy of the "original" score from the Österreichische Nationalbibliothek in Vienna. The answer from Dr. Günter Brosche, director of the Musiksammlung in the ÖNB, was puzzling: "Unless more information is available" - he wrote "the Library is unable to help as there is no such work listed in their catalogue, neither under Sacrati's name nor in the title index." Yet the correspondence between Dr. Johann and Professor Sandberger mentions the score.

Recent sources consulted on early Venetian opera and of Sacrati's stature added further confusion to the problem. Few seventeenth-century publications were accorded more importance in the survey of Venetian musical life than Minerva al tavolino by Cristoforo Ivanovich (1681-1688). Its accumulated data has been quoted and referred to by scholars and musicians as the only reliable contemporary account of works, dates, composers and poets during the formative years of opera in Venice. This unanimous admiration was shattered in 1976 by Thomas Walker's article in which he questions Ivanovich's accuracy and demonstrates that many mistakes were committed in the identification of composers and poets (Walker 1976: 7-20). The two composers most frequently credited with the authorship of operas actually composed by others were Cavalli and Sacrati. Ivanovich, as Walker explains, moved to Venice around 1657, and hence - contrary to earlier assumptions - was not an eye-witness to the first twenty years of operatic development in the city. Whether it was misinformation or careless research that caused Ivanovich to favour Cavalli and Sacrati is hard to determine; nevertheless, the numerous

4 Alois Franz Simon Joseph Molitor (1766-1848) was a German-born composer who moved to Vienna in 1790 and became well known there as a violinist, chamber musician and highly rated composer of guitar music. After a brief period as conductor of the Venice orchestra, he was forced to flee the city in 1797 during Napoleon's victorious Italian campaign. Upon returning to Vienna he accepted a civil service position which he maintained until his retirement in 1831. Despite his office work, Molitor actively participated in Vienna's musical life. His interest in Baroque music, especially in the development of the Hofoper and the Hofkapelle in the Habsburg court, led him to the mostly forgotten opera manuscript collection in the Hofbibliothek which he helped to organize and catalogue. 
errors listed by Walker discredit the reliability of his work in matters related to the early period of Venetian opera (Walker: 10-11).

This study addresses two problems: one, the identity of the composer of the Proserpina rapita fragment, and two, the whereabouts of the original manuscript that served as the source for the Munich/Vienna excerpts.

A thorough search investigating the background of Proserpina rapita reveals the following:

1. The composer Claudio Monteverdi was commissioned by the Mozzenigo family to compose an opera for their daughter's wedding to Lorenzo Giustiniani. Set to Giulio Strozzi's libretto, Proserpina rapita was presented during the wedding festivities at the Mozzenigo Palace in 1630. The Biblioteca Marciano in Venice houses an original printed copy of the libretto (dated 1630); Monteverdi's name is given on the title page as the composer of the piece. The music, however, has been lost with the exception of the vocal trio: "Come dolci hoggi" (Tutte le opere 1930 [1942]: IX/60-67).

Proserpina rapita. Anatopismo del signor GIULIO STROZZI, honorato di Musica del signor CLAUDIO MONTEVERDI e rappresentato in Venetia ne' fortunatissimi sponsati degli Illustrissimi signori Giustiniana Mozzenigo e Lorenzo Giustiniani.

("Proserpina rapita. Anatopismo** by Giulio Strozzi, honored with the music of Claudio Monteverdi and represented in Venice at the happy wedding of the illustrious Giustiniana Mozzenigo and Lorenzo Giustiniani.") [Solerti 1904: 146]

2. Ivanovich states that Strozzi's text was set to music a second time by Francesco Sacrati in 1644 and premiered as the opening work of the new season at the St. Moisè theatre. While a new edition of Strozzi's text had been published in 1644, there is no reference to Sacrati's music in the libretto. The cover, reproduced by Livio Niso Galvani in I teatri musicali di Venezia nel secolo XVII, is identical with that of the 1630 edition (Galvani 1879: 57).

Il libretto non presenta nessuna indicazione di nuove rappresentazioni sia della prima versione, sia di un' eventuale nuova composizione di Sacrati. Reca l'indicazione 'secunda impressione' e contiena la dedica datata dell' edizione originale e un testo identico, a parte qualche insignificante errore di stampa.

** Anatopismo - a fanciful play where neither the geological nor the mythological facts are quite correct, yet it seems effective on the stage. 
Vi si ritrovano perfino le numerose descrizioni della musica, come quella già citata. Con tutta probilità l'edizione del 1644 è una ristampa a scopo puramente letterario.

("The libretto does not present any indication of a new production either of the first version or of an eventual new composition by Sacrati. It bears the indication 'second printing' and contains the dedication given with the original edition to an identical text, apart from some insignificant printing mistakes. Here one can see, once again, the numerous descriptions of the music like that already cited. In all probability, the 1644 edition is a reprint for a purely literary purpose.") [Walker: 14]

3. There also exists strong evidence against the location of the performance in the St. Moisè theatre. Newly examined state papers and general archival material agree that the theatre was closed during the 1644 season and for the subsequent three years (Monterosso-Vacchelli 1977: I). ${ }^{5}$

... ma non è chiara la ragione per cui abbia assegnato l'opera al Teatro $S$. Moisè; forse perché altrimenti in quel teatro non sa sarebbe rappresentata nessuna opere in quell' anno. Cosa che non ci furono rappresentazioni a $S$. Moisè per le tre stagioni successive, $\mathrm{e}$ che il teatro fu riaperto nel $1648 \mathrm{o}$ forse anche dopo.

(“. . but it is not clear why the S. Moisè was indicated as the theatre where the performance took place; maybe because otherwise there were no other opera presentations in that year. This question should not preoccupy us since we know that there were no opera performances at the $S$. Moisè during the next three years either, and that the house reopened only in 1648.") [ibid.: 13]

In view of these facts it seems reasonable to omit Sacrati's name as the probable composer of the Munich/Vienna fragment and to look for alternative solutions.

Franz Stieger's Opernlexikon lists two additional seventeenth century Italian operas entitled Proserpina rapita, apart from Monteverdi's and Sacrati's (1975: I/3/989). Of these the first names Principe de Gallico as the composer of a work performed in Rome in 1645 based on Strozzi's text. If this listing refers to a manuscript in the British Library, R.M.23.f.8., Stieger's information is erroneous (Hughes-Hughes 1906-9: 2). W. B. Squire ascribes the

5 In a well-documented discussion Monterosso-Vacchelli examines the circumstances of the alleged new setting of music for Proserpina rapita by Sacrati and its presentation at the $\mathrm{S}$. Moisè theatre. 
anonymous score to Pompeo Colonna, Prince of Gallicano; the latest research, however, seems to disregard this suggestion and leaves the name of the composer open to question (New Grove 1980: 4/583). The second piece, an intermedio, composed by Benedetto Ferrari on his own text and presented with La ninfa avara at the Teatro S. Moisè in Venice (around 1641), has been lost (Whenham: 6/491).

There is yet another anonymous Proserpina MS in the British Library (not catalogued by Stieger), Additional 16,111. According to Hughes-Hughes, a pencil note on $\mathrm{f}$. 136 identifies the opera as La Proserpina by Pollaroli (HughesHughes 1906-09: 2/239).

A brief perusal of the two scores in the British Library yielded negative results; neither the text nor the music matches that of the Munich/Vienna fragment. Similarly disappointing was a second letter from the Österreichische Nationalbibliothek in reference to the location of the original music which served as the source of the excerpts. In a letter to me of 8 March, 1982 Dr. Brosche wrote:

"We now can supplement our answer of November 2, 1981, by saying: the Music Division of the ÖNB does not posses the complete score of Sacrati's opera, Proserpina rapita. In the enclosure we are sending you copies from the "Example Collection of Simon Molitor" (listed: Mus. Hs. 19242/Nr. 120); this is all we have in our custody from this Drama per musica."

Appended to the letter was a xeroxed copy of the fragment in Molitor's hand; this score was the obvious "original" version used for the Munich samples. ${ }^{6} \mathrm{~A}$ crucial fact has been settled by Dr. Brosche's letter, namely that there is no complete score of this opera in the Musiksammlung in Vienna. Lack of additional musical sources prompted a change in the identification process; the text of the Munich/Vienna excerpts became the core of the subsequent investigation.

Even a cursory look at the plot points to inconsistencies. Roman mythology tells of Proserpina's sad fate: she was abducted by Pluto while picking wild flowers in a meadow with friends and carried - against her will - to the underworld where she was forced to marry him. Inexplicably, the opening

6 Professor Sandberger may have seen the Molitor score personally during a visit to Vienna, recognized its unique nature and asked for a copy for his files. This might explain the lack of extant correspondence between Dr. Lach and Professor Sandberger in the ÖNB. 
scenes of Act I of the manuscript are located in the underworld ("Reggia Plutone"). The duet of scene two starts with Pluto's words, "Che piangi amata sposa?" If Proserpina is already Pluto's wife, why does the title allude to her abduction? The answer is given in Monterosso-Vacchelli's essay on Monteverdi's later operas: "Quasi tutta l'azione si svolgeva mediante d'assieme: dal terzetto iniziale della prima scene (my italics), ove 'Proserpina, Aretusa e Ciane cantano unitamente' ..." (op. cit., 107) ${ }^{7}$ Clearly, something is amiss. Molitor's version opens with a solo, not a trio; thus the content of Strozzi's libretto and that of the Vienna/Munich fragments cannot be identical. We have here two different stories.

A musical analysis, based on melodic and harmonic elements, reveals that (1) the formal organization displays a clear distinction between recitative and aria, (2) the melodic writing of the aria and the duet contains sequences, recurring melodic patterns and regular phrase structures, and (3) tonality and functional chord progression dominate the harmonic language with occasional modal sections and cross relationships.

Thus the Proserpina rapita excerpts show musical traits akin to the Venetian tradition practiced between 1650 and 1670 . Textual evidence points to Proserpina and Pluto as part of the plot but not necessarily the main characters of the story. Therefore the title might be as spurious as the name of the composer.

An extensive survey of Venetian operas related to the Proserpina legend led eventually to Cesti's famous work, Il Pomo d'Oro. Act I, scenes one and two from the Munich/Vienna fragments are identical with the opening scenes in the first act of Cesti's opera, and the Sinfonia given in the excerpts corresponds to the prelude preceding Act II.

The composer of the Vienna/Munich manuscripts has been discovered; now the question about Molitor's role in copying the music with the erroneous title should be addressed.

Biographical data advises us that Molitor was in regular contact with Venetian musical life, first as conductor and solo violinist of the local orchestra (1796-97 season), and later as music historian and bibliographer during his frequent visits to Italian libraries in search of unpublished vocal and instrumental scores (or partbooks) from the sixteenth and seventeenth centuries (Wurzbach

7 "Almost all the action occurs by means of ensembles: the opening trio of the first scene where 'Proserpina, Aretusa and Ciana sing together' ..." 
1868: $18 /\left(\right.$ n.p.)). ${ }^{8}$ Among several portfolios, bequeathed to the Nationalbibliothek, is a handwritten folder labelled "Materialen zu einer Geschichte der Music" (Mus. Hs. 19241). The unfinished study contains a lengthy description of early Italian opera and a fairly complete list of dramatic music written by Italian composers in the seventeenth century. More than one hundred musical examples, mostly copied in Molitor's hand, are appended to the notes. The Proserpina excerpt is one of these. ${ }^{9}$

The collection displays Molitor's well organized system in the method of choosing examples which are subdivided into several categories. It seems almost certain - and the handwritten reference to Winterfeld's Gabrieli supports this assumption - that Molitor's attention was caught by the use of a brass ensemble for the accompaniment in the scenes from Proserpina. One can hardly blame him for the mistake: early Italian Baroque opera was a virtually unknown subject during the first half of the nineteenth century.

What conclusions can be drawn from the clarification process of the Proserpina fragments? Are there any practical results of these findings?

In practical terms, the two libraries - the Nationalbibliothek in Vienna and the Staatsbibliothek in Munich - can amend their catalogue listings and save many hours of frustrating search by music historians should they be confronted with Sacrati's name in one of these collections.

For scholars there is the reminder that most manuscript holdings of major libraries contain numerous complete and incomplete Baroque opera scores which carry spurious titles or are attributed to the wrong composer. Thus a systematic research to list suspected scores, and an undertaking (based on comparison) to identify these works, are long overdue. A comprehensive venture of this nature could uncover material presently thought to be lost.

Finally, there remains the unresolved question concerning the whereabouts of

8 In later life Molitor was closely associated with R. G. Kiesewetter in the rediscovery and private presentations of early music for small select audiences of professional and amateur musicians. It was in search for more material, to be performed at these concerts, that he travelled to Italy regularly.

9 Molitor notes on the first page of the Proserpina excerpt: "der 3' Akt fehlt." This comment hints that the "original" score must have contained two fairly complete acts of music. 
the original music from which Molitor copied his samples. It is possible that the large-scale enterprise, conducted presently by a group of internationally known musicologists to assemble and catalogue all extant seventeenth century Italian operas, will ultimately lead to the missing "original" score of the Proserpina rapita. 
- Proserpina rapita
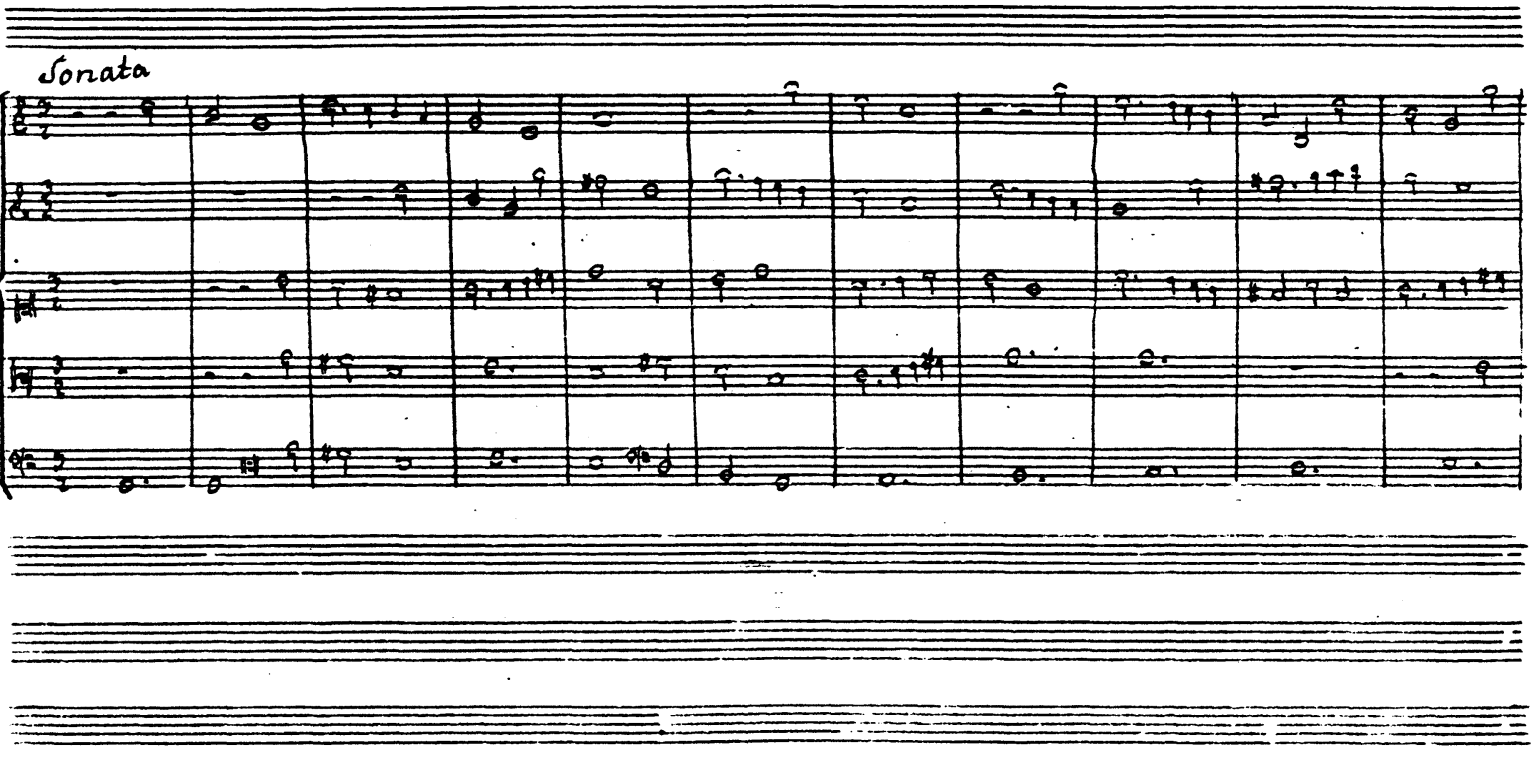

sonstabt tofe. 

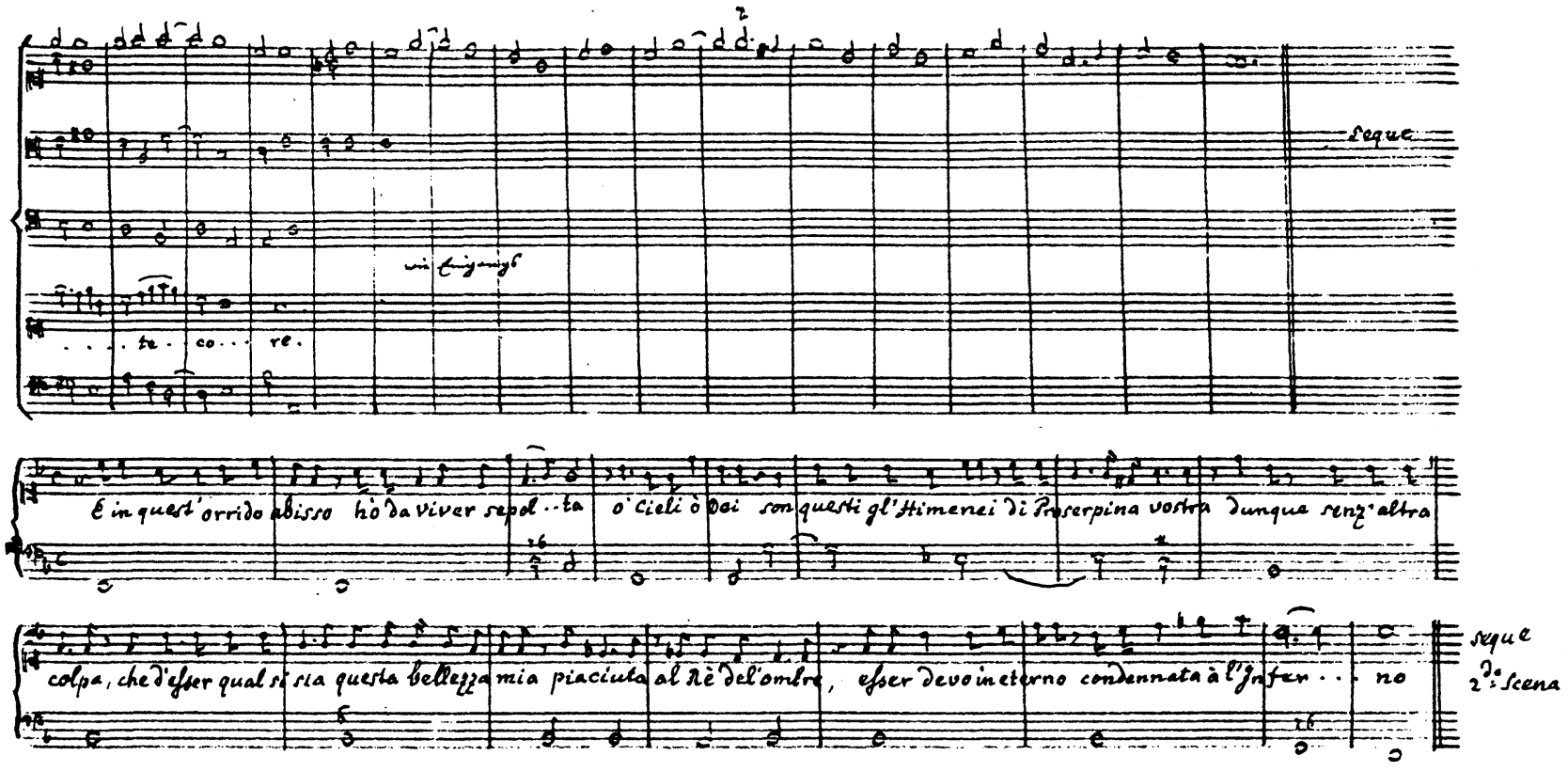

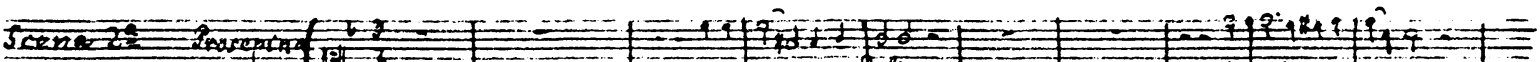

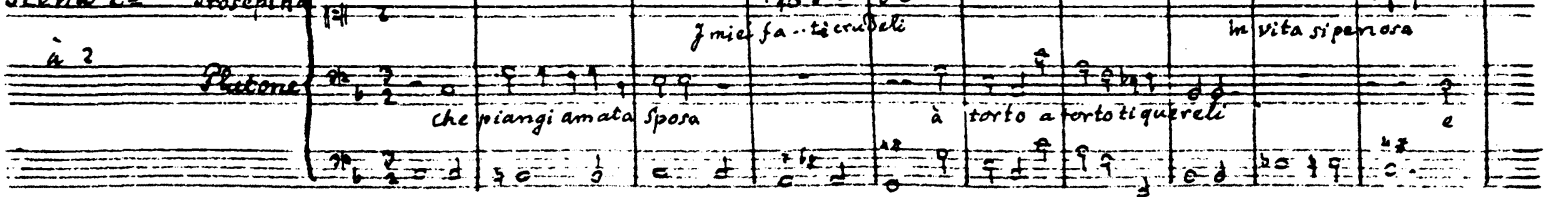


APPENDIX LISTING OF SEVENTEENTH \& EIGHTEENTH CENTURY OPERAS BASED ON THE PROSERPINA SUBJECT

\begin{tabular}{|c|c|c|c|c|}
\hline Title & Composer/Librettist & Medium & Location/Date & Remarks \\
\hline \multicolumn{5}{|c|}{ (Italian works, seventeenth century) } \\
\hline Proserpina rapita & Girol. Giacobbi (no libr.) & intermedio & Bologna, 1613 & \\
\hline (La) Proserpina rapita & Monteverdi/Strozzi & opera & Venice, 1630 & $\begin{array}{l}\text { private performance for a } \\
\text { wedding }\end{array}$ \\
\hline Proserpina rapita & Sacrati/Strozzi & opera & Venice, 1644 & apparently ironeous \\
\hline Proserpina rapita & Pollaroli (?), (no libr.) & opera & Venice?,? & $\begin{array}{l}\text { identification of the composer is } \\
\text { uncertain }\end{array}$ \\
\hline Proserpina rapita & ? /(Colonna?) & opera & Rome (?), 1645 & score in the British Library \\
\hline Proserpina rapita & B. Ferrari & intermedio & Bologna, 1645 & music is lost \\
\hline \multicolumn{5}{|l|}{ (French works) } \\
\hline Proserpine & Lully/Quinault & tragédie lyrique & St. Germain/Paris, 1680 & \\
\hline Proserpine & J. B. Stuck & tragédie lyrique & Versailles, 1714 & \\
\hline \multicolumn{5}{|l|}{ (Swedish opera) } \\
\hline Proserpine & J. Krauss/Kellgreen & opera in 1 act & Stockholm, 1781 & \\
\hline \multicolumn{5}{|l|}{ (English work) } \\
\hline The Rape of Proserpina & J. E. Galliard/Theobald & farce in 1 act & London, 1726 & performed in Lincoln's Inn Field \\
\hline \multicolumn{5}{|l|}{ (German works) } \\
\hline Der Raab der Proserpine & S. Capricornus/? & Kantate/Singspiel & Stuttgart, ca. 1660 & \\
\hline Die geraubte Proserpine & $? / ?$ & Singspiel & Koburg, 1683 & \\
\hline
\end{tabular}




\begin{tabular}{|c|c|c|c|c|}
\hline $\begin{array}{l}\text { Die von Pluto geraubte } \\
\text { Proserpine }\end{array}$ & $? / ?$ & Singspiel & $\begin{array}{l}\text { Bayreuth, } 1708 \text {, and Theatre } \\
\text { St Georges am See, } 1717\end{array}$ & \\
\hline Der Raab der Proserpine & F. Deller/Noverre & ballet & Stuttgart, 1766 & \\
\hline Proserpine & v. Seckendorf/Goethe & monodrama & Weimar, 1778 & \\
\hline \multicolumn{5}{|l|}{ (Spanish opera) } \\
\hline El robo de Proserpina & F. Copola/Porsile & opera & Naples, 1677 & \\
\hline \multicolumn{5}{|c|}{ (Italian late-eighteenth century works) } \\
\hline Il ratto di Proserpina & Asioli/? & intermedio & Coreggio, 1784 & performed in the Teatro Pubblico \\
\hline $\begin{array}{l}\text { Il ratto di Proserpina } \\
\text { Il ratto di Proserpina }\end{array}$ & $\begin{array}{l}\text { J. C. deSilva/Martinellu } \\
\text { G. B. Cimador/Botturini }\end{array}$ & $\begin{array}{l}\text { opera in } 2 \text { acts } \\
\text { opera in } 2 \text { acts }\end{array}$ & $\begin{array}{l}\text { Lisbon, } 1784 \\
\text { Venice, } 1791\end{array}$ & during carnival time \\
\hline
\end{tabular}




\section{REFERENCES}

GALVANI, L. N.

1879: I Teatri Musicali di Venezia nel Secolo XVII (1637-1700). Bologna:

Forni.

HUGHES-HUGHES, A.

1906-9: Catalogue of Manuscript Music. 3 volumes, London. [R 1964].

IVANOVICH, C.

1681, 2/1688: Minerva al tavolino. Venezia.

MALIPIERO, G. F. (ed.)

1930, 1942: Tutte le opere de Claudio Monteverdi. No. 9425, Universal Edition.

MONTEROSSO-VACCHELLI, A. M.

1977: "Claudio Monteverdi" in G. Barblan and A. Basso, eds. Storia dell' Opera. UTET.

NEW GROVE DICTIONARY OF MUSIC

1980: "Colonna" in vol. 4 (no author). S. Sadie, ed. London: MacMillan.

SOLERTI, A.

1904-5: Gli Albori del Melodramma. 3 volumes. Milano. [R 1969].

SQUIRE, W. B.

1925: "An Opera under Innocent X," in Gedenkenboek Dr. D. F. Scheurleer. Gravenhagen: Nijhoff.

SQUIRE, W. B. and ANDREWS, H. eds.

1927-29: Catalogue of the King's Music. 3 volumes. London.

STIEGER, F.

1975-83: Opernlexikon. 10 volumes. Tutzing: Schneider.

WALKER, T.

1976: "Gli errori di Minerva al tavolino," in M. T. Muraro, ed. Venezia e il melodramma nel Seicento. Firenze.

WALKER, T.

1980: "Sacrati" in New Grove Dictionary of Music, vol. 16. S. Sadie, ed. London: MacMillan.

WHENHAM, J.

1980: "Ferrari" in New Grove Dictionary of Music, vol. 6. S. Sadie, ed. London: MacMillan.

WURZBACH, C.

1868: Biographisches Lexikon des Kaiserthums Oesterreich erhaltend. Wien. 